\title{
Utilization of Cement Kiln Dust and Fly Ash in Cement Blends in Saudi Arabia
}

\author{
M. A. DAOUS \\ Chemical \& Materials Engineering Department, KAAU \\ P. O. Box 80204, Jeddah 21589, Saudi Arabia \\ mdaous@kau.edu.sa
}

\begin{abstract}
Cement kiln dust produced in a local cement production plant in Saudi Arabia, along with fly ash resulting from combustion of heavy fuel oil in a local power generation plant were utilized as waste materials blended with ordinary Portland cement at various ratios. These blends were tested for their water requirements for normal consistency, initial setting times, and compression and tensile strengths, and were compared to those of Portland cement. Test results show that satisfactory mechanical strength (a minimum of $94 \%$ of compression strength of ordinary Portland cement) can still be achieved in blends utilizing $90 \%$ cement and not more than $4 \%$ fly ash. Adequate mechanical strengths (a minimum of $80 \%$ of compression strength of Portland cement) were achieved in blends utilizing as little as $70 \%$ cement when only kiln dust was blended.
\end{abstract}

Keywords: cement kiln dust; fly ash; cement blends; blend properties

\section{Introduction}

Hundred thousands of tons of cement-kiln dust (CKD) are generated annually from cement plants in the Kingdom of Saudi Arabia. The bulk of this dust, mostly with high alkali contents, is land filled with a significant financial loss to the local cement industry in terms of the value of raw materials, processing, and energy consumption during pyroprocessing, dust collection, and disposal. This fine dust is emitted from cement kilns to prevent the build up of excessive salts in the cement product. The alkali salts in the dust are derived from the clay raw 
materials, which include potassium and sodium feldspars. CKD consists mainly of partially calcined kiln feed, and as such, is generally suitable for recycling to the kiln. However, continuous recycling of CKD to the kiln can soon offset the equilibrium between the alkali levels in the kiln feed and the internal cycle of volatilization and condensation within the kiln, resulting in high alkali clinker. This, of course, is not suitable for plants intending to make low alkali cements that meet the national Saudi requirement of low alkali cement, which specifies a limit of $0.6 \%$ equivalent of $\mathrm{Na}_{2} \mathrm{O}$ for contained alkali. The alkali content must be kept low to prevent concrete decrepitation, which might result from a reaction between the alkali and silica in some reactive aggregates in concrete.

Various methods for utilizing CKD in industrial applications, including existing or proposed methods for alkali removal, are reported in the literature. Bhatty [1] provides a general review of these methods. Because of the generally high lime content of CKD and subsequent ability to harden upon exposure to moisture, CKD has been used as a binder in soil stabilization suitable for a subbase in streets and high way construction. It is commonly used as a mixture with different solid- waste materials such as waste glass, fly ash, waste water sludge with the addition of cement or other admixtures if necessary [2-6].

Alkalis may be removed from CKD by aqueous leaching followed by returning the washed CKD to the kiln [7-9], or by fluidized bed technology to volatilize alkalis [10]. A number of patents have been issued dealing with the extraction of soluble potassium salts that are later recovered as a saleable product and the water recovered for reuse $[8,11,12]$. The potassium-free dust is usually recycled as a kiln feed.

A great deal of work has been done on the use of CKD in blended cements. Bhatty has published a series of reports [13-16] on the addition CKD Portland cement along with fly ash and blast furnace slag, with variable results. Cements blended with CKD alone reportedly had reduced strength, setting time, and workability. The strength loss was attributed to the presence of high alkalis in the dust. The addition of fly ash with CKD lowered the alkalis contents and resulted in improved strength. Additions of slag generally reduced workability but improved blends' strengths because of activation from the high lime content of CKD.

Bhatty's results also demonstrated that particular ratios of alkalis, chlorides, and sulfates are important for better performance of cement blends. A high sulfate blend, for instance, gave a high strength. However, high alkali contents results into increased susceptibility to alkali - aggregate reaction, which may be blocked by the slag or fly ash constituents. Based on similar data, Sanduo [17] suggested that the use of finely ground limestone and cement kiln dust should 
be allowed in standard ASTM specifications for Portland cements.

Daugherty and Funnell [18] have also evaluated the use of CKD by grinding and blending this dust with Portland cement. Their data showed no evidence of adverse effects on blends' setting time, soundness, or shrinkage with up to $10 \%$ CKD addition. These blends' strengths, however, varied probably because of variations in composition of dust used in these blends. ElDidamony et al [19] studied the role of CKD in some blended cement pastes. Results of adding CKD to either Portland cement or to blast furnace slag cements were reported. These researchers found that adding CKD to blends of ordinary Portland cement, blast furnace slag cement, or sulfate resistant cement beyond specific upper limits to each of these blends adversely affected the physical and mechanical properties of these blended cement pastes.

Strunge et al. [20,21] discussed the role volatile alkalis $\left(\mathrm{Na}_{2} \mathrm{O}, \mathrm{K}_{2} \mathrm{O}\right)$ present in CKD play on blends' properties. They reported that when salts other than sulfates are present, both of these alkalis are preferentially incorporated into $\mathrm{C}_{3} \mathrm{~A}$ to give orthorhombic form. $\mathrm{N}_{2} \mathrm{O}$ orthorhombic $\mathrm{C}_{3} \mathrm{~A}$ is retarded in hydration, while that of $\mathrm{K}_{2} \mathrm{O}$ is accelerated. They also reported that when these alkalis are present as sulfates, cement setting as well as compressive strength development is accelerated.

Klemm [22] pointed out that blended cements containing CKD can work out satisfactory only if the alkali content is not excessive, otherwise fly ash or blast furnace slag should be added to reduce potential alkali - aggregate reaction problems. Strength development in Portland cement pastes with the addition of kiln meal and kiln dust was investigated [23-25]. Samples of ordinary Portland cement blended with cement dust generally witnessed a decrease in their compressive and tensile strength with increasing dust percentage in these blends. However, a slight increase in these mechanical properties was observed in samples utilizing blends of cement dust with either blast furnace slag cement or sulfate resistant cements.

El-Sayed et al. [26] have investigated the effect of CKD on the compressive strength of cement paste and on the corrosion behavior of embedded reinforcement. They reported that substitution of up to $5 \%$ by weight of cement by CKD produced no adverse effect on the cement paste strength or on the reinforcement passivity. A similar conclusion was reached by an investigation carried out by Batis et al. [27]. Al-Harthy et al. [28] investigated the use of $\mathrm{CKD}$ as a substitute for Portland cement at different proportions in concrete and mortar samples. They also concluded that substitution of cement with CKD does not produce negative effects on strength properties of these samples when CKD was added at proper low ratios. 
The utilization of different types and classes of fly ash as a partial replacement of cement or aggregates in concrete mixes or as an additive in different blends of cement mortars has been investigated by many researchers in the last few years. It has been reported that such utilization produces various technical, economical, and environmental benefits [29-41]. These studies also show that the resulting mechanical properties of blended mortars depend to a large extent on type of fly ash used, its source, fuel type, combustion temperature, particle size, and other factors.

The chemical, mineralogical, and physical compositions of CKD varies from one plant to another. These depend on raw material, type of kiln operation, dust collection method, and type of fuel used in the plant [7]. Therefore, the objective of the present work is to investigate the effect of adding CKD, produced from a local Saudi cement plant and fly ash residue from a local power generation plant, on the physical properties of blended ordinary Portland cement mortars.

\section{Materials}

Ordinary Portland cement and cement kiln dust produced locally by the Arabian Cement Company Ltd in Rabigh, Saudi Arabia were used in the experimental work of this study. The chemical analyses of these materials are given in Table (1). The CKD had a density of $3.08 \mathrm{~g} / \mathrm{cm} 3$, a bulk density of 1.17 , and a porosity of 0.62 .

Fly ash resulting from combustion of heavy fuel oil in the power generation plant of the Saudi Consolidated Electric Company in Rabigh was also used. Chemical analysis of the fly ash is given in Table (2).

Table (1). Analysis of Portland cement and CKD, weight percent

\begin{tabular}{|l|l|l|}
\hline Constituent & Portland cement & CKD \\
\hline $\mathrm{CaO}$ & 63.77 & 42.02 \\
\hline $\mathrm{SiO}_{2}$ & 20.36 & 14.42 \\
\hline $\mathrm{Al}_{2} \mathrm{O}_{3}$ & 5.33 & 4.14 \\
\hline $\mathrm{Fe}_{2} \mathrm{O}_{3}$ & 3.97 & 2.67 \\
\hline $\mathrm{MgO}$ & 2.10 & 1.55 \\
\hline $\mathrm{K}_{2} \mathrm{O}$ & 0.14 & 3.26 \\
\hline $\mathrm{Na}_{2} \mathrm{O}$ & 0.48 & 2.60 \\
\hline $\mathrm{SO}_{3}$ & 2.72 & 2.47 \\
\hline $\mathrm{Cl}^{-1}$ & 0.03 & 4.12 \\
\hline
\end{tabular}


Table 2. Heavy fuel oil ash analysis

\begin{tabular}{|l|l|}
\hline \multicolumn{1}{|c|}{ Parameter } & Quantity \\
\hline $\mathrm{PH} @ 18^{\circ} \mathrm{C}$ & 2.8 \\
\hline Moisture & $0.33 \mathrm{wt} \%$ \\
\hline Unburned Carbon $@ 700^{\circ} \mathrm{C}$ & $90.18 \mathrm{wt} \%$ \\
\hline Ash Content & $9.82 \mathrm{wt} \%$ \\
\hline $\mathrm{SO}_{3}$ & $3.06 \mathrm{wt} \%$ \\
\hline Vanadium as V & $4007 \mathrm{ppm}$ \\
\hline Nickel as Ni & $1021 \mathrm{ppm}$ \\
\hline Iron as Fe & $559.4 \mathrm{ppm}$ \\
\hline Magnesium as $\mathrm{Mg}$ & $1800 \mathrm{ppm}$ \\
\hline
\end{tabular}

Local silica sand that pass a minus 200-mesh screen was used. It had a specific gravity of 2.6 , and water absorption of $1.4 \%$ by weight. Sand used in preparing all mortar specimens was presoaked in water for 24 hours.

\section{Experimental Program}

Four sets of experiments were carried out in this study to determine the following:

(a) Normal consistency of blended cement pastes of different weight percent of Portland cement, CKD, and fly ash, as shown in Table (3), according to ASTM specifications (C 187-94) [42].

(b) Initial time of setting for the blends of Table (3), according to ASTM specification (C 191-94) [43].

(c) Compressive and tensile strength of hydraulic cement mortars blended with different ratios of CKD, and fly ash, as indicated in table (3), according to ASTM specifications (C 109-94) [44], and (C 190-94) [45], respectively.

Table 3. Composition of different cement, CKD, and fly ash blends employed.

\begin{tabular}{|c|c|c|c|c|c|c|c|c|c|}
\hline \multicolumn{2}{|c|}{$\begin{array}{l}\text { Blend } 1 \\
90 \% \text { PC }\end{array}$} & \multicolumn{2}{|c|}{$\begin{array}{l}\text { Blend } 2 \\
80 \% \text { PC } \\
\end{array}$} & \multicolumn{2}{|c|}{$\begin{array}{l}\text { Blend } 3 \\
70 \% \text { PC } \\
\end{array}$} & \multicolumn{2}{|c|}{$\begin{array}{l}\text { Blend } 4 \\
60 \% \text { PC } \\
\end{array}$} & \multicolumn{2}{|c|}{$\begin{array}{l}\text { Blend } 5 \\
40 \% \text { PC }\end{array}$} \\
\hline $\begin{array}{l}\text { CKD } \\
(\%)\end{array}$ & $\begin{array}{l}\text { FA } \\
(\%)\end{array}$ & $\begin{array}{c}\text { CKD } \\
(\%)\end{array}$ & $\begin{array}{l}\text { FA } \\
(\%) \\
\end{array}$ & $\begin{array}{c}\text { CKD } \\
(\%)\end{array}$ & $\begin{array}{l}\text { FA } \\
(\%) \\
\end{array}$ & $\begin{array}{l}\text { CKD } \\
(\%)\end{array}$ & $\begin{array}{l}\text { FA } \\
(\%)\end{array}$ & $\begin{array}{l}\text { CKD } \\
(\%)\end{array}$ & $\begin{array}{l}\text { FA } \\
(\%) \\
\end{array}$ \\
\hline 10 & 0 & 20 & 0 & 30 & 0 & 40 & 0 & 60 & 0 \\
\hline 8 & 2 & 16 & 4 & 24 & 6 & 32 & 8 & 48 & 12 \\
\hline 6 & 4 & 12 & 8 & 18 & 12 & 24 & 16 & 36 & 24 \\
\hline 4 & 6 & 8 & 12 & 12 & 18 & 16 & 24 & 24 & 36 \\
\hline 2 & 8 & 4 & 16 & 6 & 24 & 8 & 32 & 12 & 48 \\
\hline 0 & 10 & 0 & 20 & 0 & 30 & 0 & 40 & 0 & 60 \\
\hline
\end{tabular}


The following conditions were observed in preparing all specimens for the compressive and tensile strength tests:

(a) The sand to Portland cement weight ratio was fixed at 3:1. The used sand was presoaked in water for 24 hours

(b) The density of all specimens was maintained at a value of 2.4 $\mathrm{g} / \mathrm{cm}^{3}$ at preparation, by fixing the mass of the hydraulic mortar specimens for the designated volume of the mold used in that test. Thus, for the $50 \mathrm{~mm}$ cube specimens of the compression test; for example, the total hydraulic mass of each specimen was kept at $300 \mathrm{~g}$.

(c) The required water for each mortar specimen of a given cement, $\mathrm{CKD}$, and fly ash blend composition was based on the percentage of water required to produce a neat blend of normal consistency as measured for that blend composition.

(d) Three mortar specimens of each cement, CKD, and fly ash blend shown in Table (3) were tested for compressive and tensile strength after curing for 7 and 28 days.

\section{Results and Discussion}

Increasing the ratio of waste materials in the blended cement paste significantly increased the amount of water required to produce a neat blend of normal consistency. This increase is mainly due to the presence of the dry fly ash in the blend, which does not contribute to the hydration reactions. The increase in hydration requirement became less significant as CKD became the dominant waste material blended, and practically diminished when only CKD was blended with Portland cement, as shown in Fig. 1.

Increasing the percentage of waste materials in the cement blend has also significantly increased the initial setting time of these blends. This increase became prohibitively large for all blends containing less than $70 \%$ cement, which is reflected on the complete loss of mechanical properties of blends containing $70 \%$ or less cement and less than $80 \%$ CKD in the blended waste material, as shown in Fig. 3 to 6. A large jump in setting time was observed in blends containing less than $90 \%$ cement when fly ash exceeded $40 \%$ of waste materials blended, as shown in Fig. 2. This figure, however, shows that the increase in setting time for blends utilizing $90 \%$ cement gradually became insignificant as the percentage of CKD in the blended waste material was increased. 


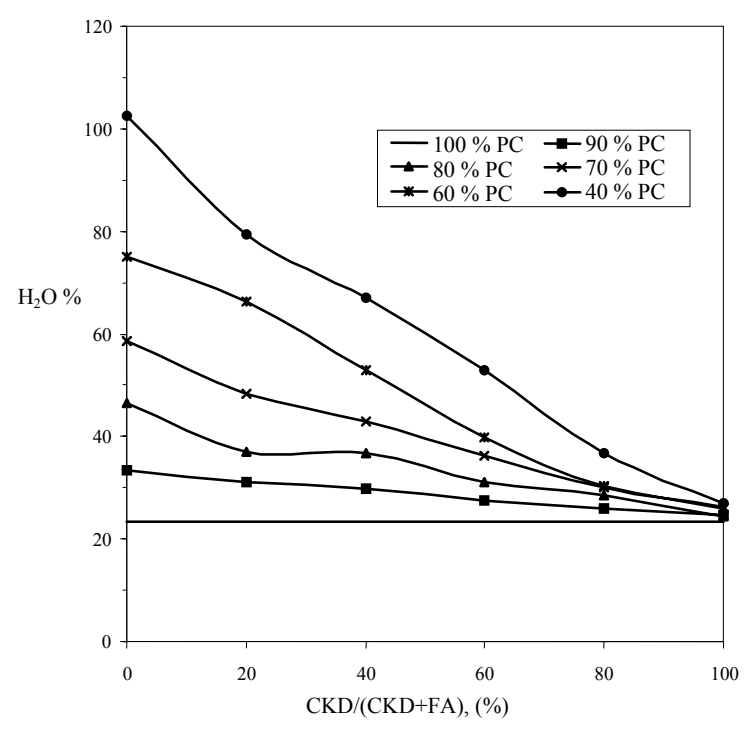

Fig. 1: Water requirement for normal consistency in different composition cement blends of CKD blended waste material.

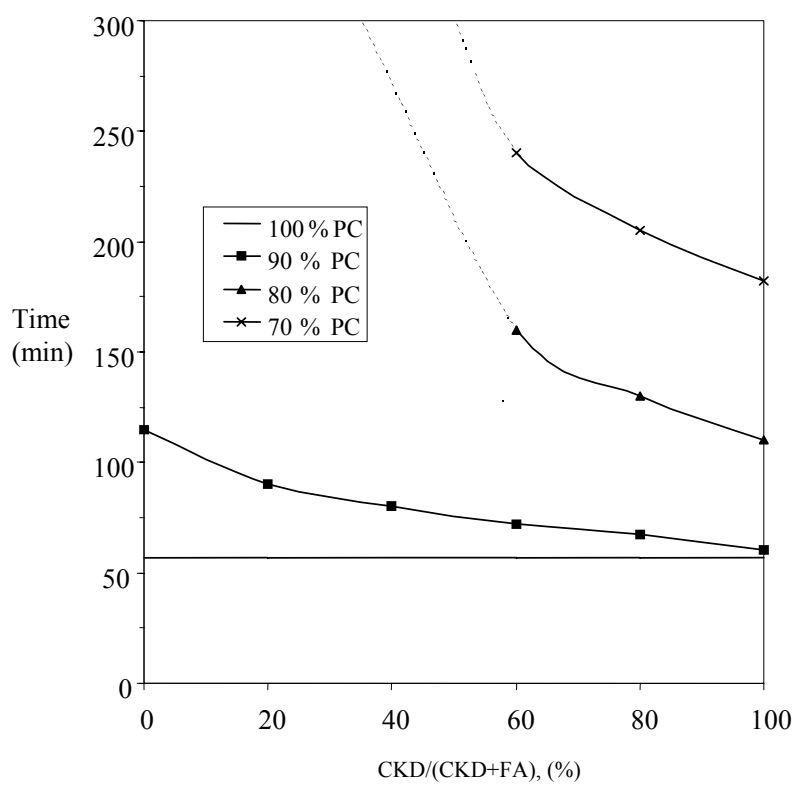

Fig. 2: Initial setting time of different composition cement blends vs. percent of CKD in blended waste materials . 


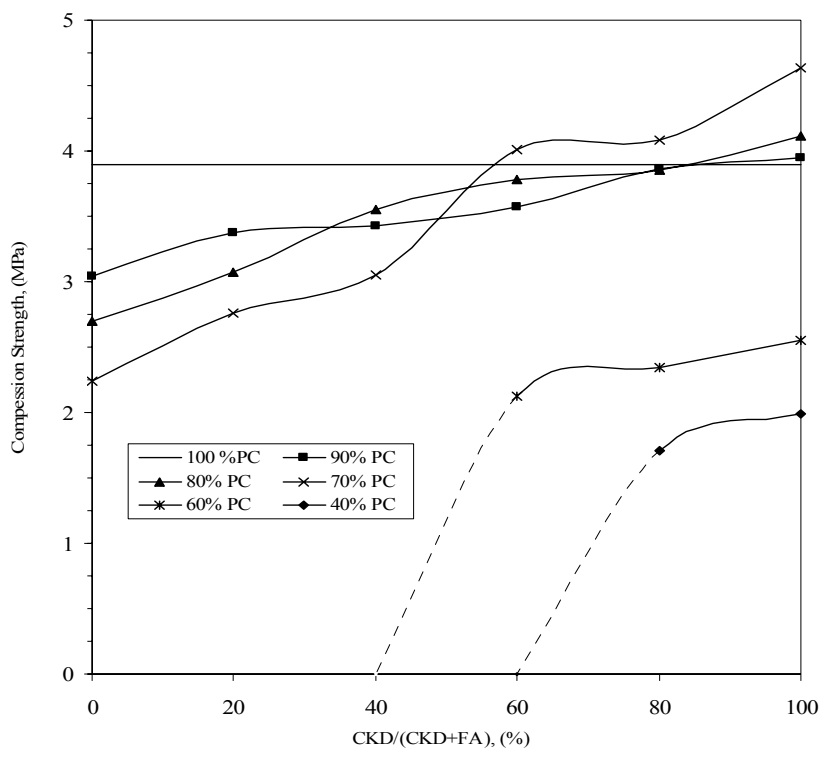

Fig. 3: Compression strength of different composition cement mortars cured for 7 days vs. percent of CKD in blended waste materials.

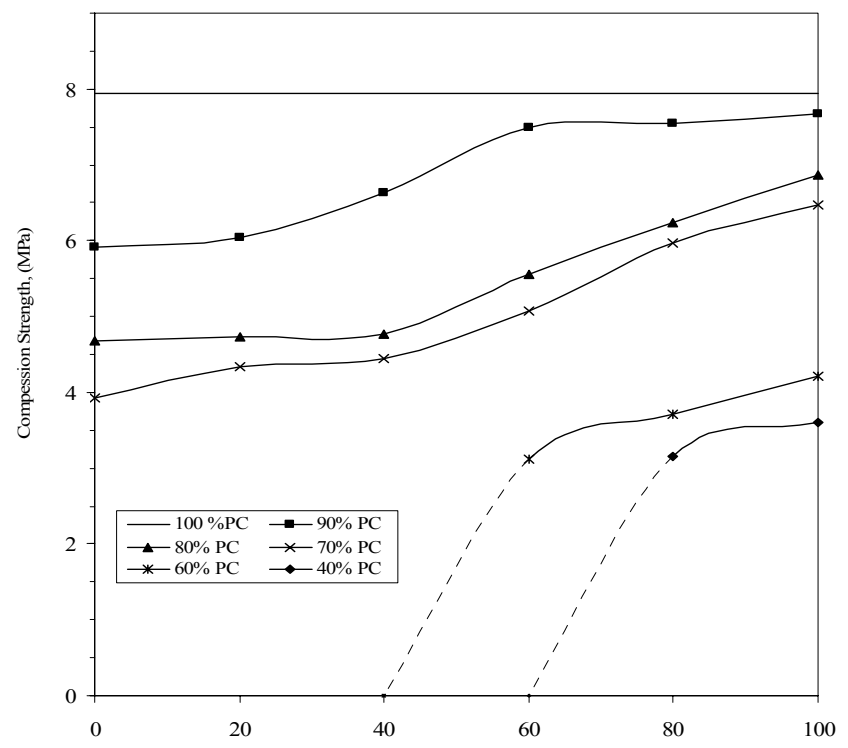

Fig. 4: Compression strength of different composition cement mortars cured for 28 days vs. percent of CKD in blended waste materials. 


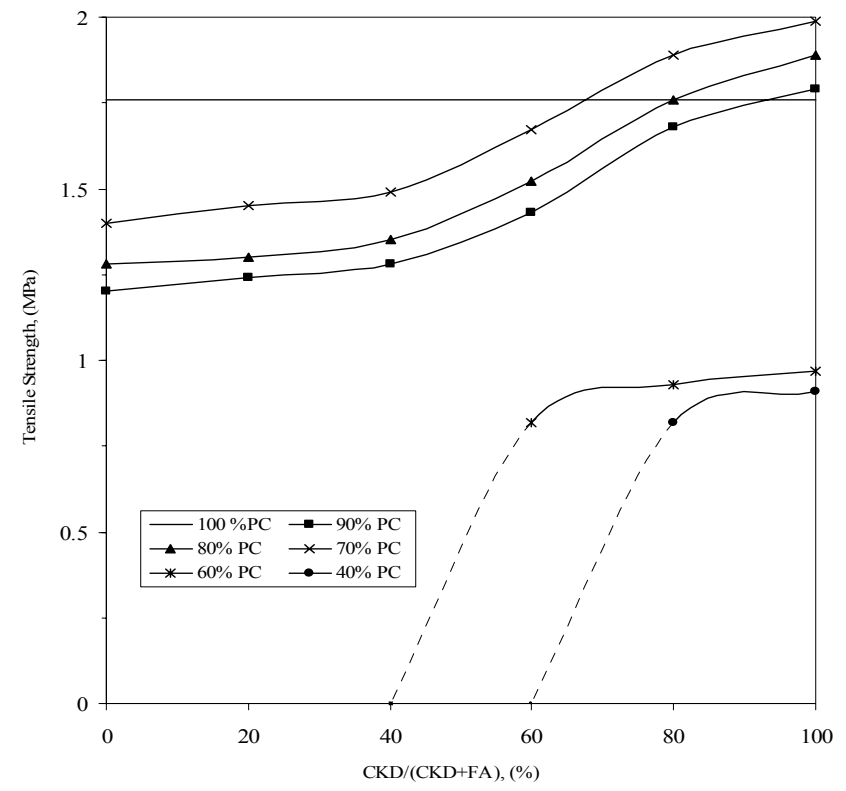

Fig. 5: Tensile strength of different composition cement mortars cured for 7 days vs. percent of CKD in blended waste materials.

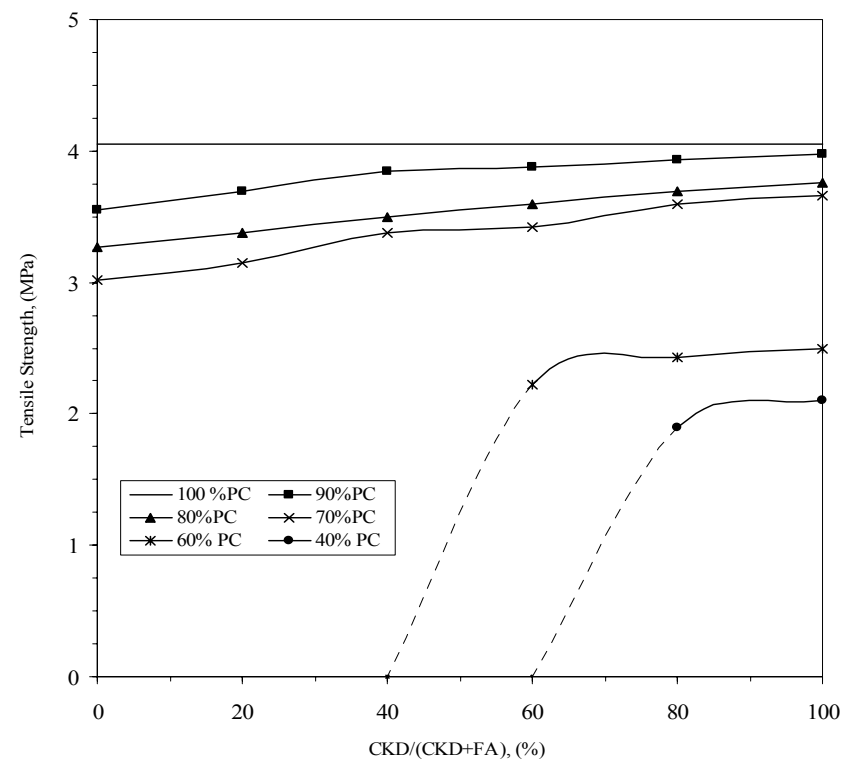

Fig. 6: Tensile strength of different composition cement mortars cured for 28 days vs. percent of CKD in blended waste materials. 
Figures 3 to 6 show that mortar-specimens prepared with less than $90 \%$ Portland cement suffered, in general, a significant decrease in mechanical strength. Increasing the ratio of fly ash in the blended waste materials further extenuated this loss in mechanical properties. However, mortar-specimens containing $70 \%$ or more cement and $60 \%$ or more CKD in the blended waste material exhibited a transient increase in their mechanical properties upon being cured for 7 days as shown in Fig. 3 and 5. This could be attributed to the chemical composition and crystalline form of alkalis present in CKD, which accelerate the hydration reactions of the cement compounds in these particular blends compositions as has been reported by Strung, et al. [20, 21]. The transient behavior of these specific blends, however, does not continue beyond the initial 7 day period as reflected by the mechanical properties of these specimens at the 28 day curing period depicted in Fig. 4 and 6.

Figures 4 and 6, which depict mechanical properties of different composition cement mortars cured for 28 days, show that specimens prepared with $90 \%$ Portland cement exhibited satisfactory strength when the ratio of CKD was maintained at $6 \%$ or higher in the blend. These specimens maintained a minimum of $94 \%$ of compression strength and $95 \%$ of tensile strength of a mortar specimen prepared with $100 \%$ cement upon aging for 28 days. The increase in hydration requirement, and initial setting time for such blends were $18 \%$ and $41 \%$, respectively at maximum. Furthermore, the data also show that blends containing as low as $70 \%$ Portland cement exhibited adequate strength ( $80 \%$ of the compression strength, and $90 \%$ of tensile strength of $100 \%$ cement blends, at minimum), when CKD alone was used as the blending waste material. The maximum increase in hydration requirement for these blends was only $10 \%$, while the increase in setting time reached up to $220 \%$.

\section{Conclusions}

CKD produced in a local cement production plant in Saudi Arabia along with fly ash resulting from combustion of heavy fuel oil in a local power generation plant were utilized as waste material blends with Portland cement, produced from the local plant, at various proportions. The following conclusions can be made concerning the performance of such blends:

(1) Mortars of satisfactory mechanical strength can still be produced using blends containing $90 \%$ Portland cement but not more than $4 \%$ fly ash as blended waste material.

(2) Blends containing as low as $70 \%$ Portland cement can still exhibit adequate strength if only CKD is used as the blending waste material.

(3) These blends witness various degrees of increase in their hydration requirements for normal consistency, and more noticeably in their initial setting times. 


\section{Acknowledgment}

The author wishes to express his gratitude to Professor Sabri Shehati of the Civil Engineering Department of King Abdulaziz University for the valuable discussions and suggestions he offered in the course of this study and to the Civil Engineering Department for the use of the department's laboratory facilities.

\section{References}

[1] Bhatty, J.I., Alternative Uses of Cement Kiln Dust, RP 327, Portland Cement Association, Skokie, Illinois, U.S.A. 1995.

[2] Nicholson, J.P., Stabilized Mixtures, U.S. Patent No. 4,101,332, 1978.

[3] Sayah, A.I., Stabilization of Highly Expansive Clay Using Cement Kiln Dust, M.Sc. Thesis, University of Oklahoma, Norman, Oklahoma, U.S.A., 1993.

[4] University of Toledo and Nicholson Concrete \& Supply Co., Uses for Cement Kiln DustPurpose of Toledo Conference, The Blade, Toledo, Ohio, July 27, 1977.

[5] Miller, C. T., Bensch, D.G., and Colony, D.C., Use of Cement Kiln Dust and Fly Ash in Pozzolanic Concrete Base Courses, Emulsion Mix Design, Stabilization, and Compaction, Transportation Research Record 754, TRB, Washington D.C., U.S.A., PP. 36-41, 1980.

[6] Bhatty, M.S.Y., Use of Kiln Dust in Blended Cements, PCA R\&D Serial No. 1717, Portland Cement Association, Skokie, Illinois, U.S.A., 1983.

[7] Klemm, W.A., Cement Kiln Dust: A Look at its Uses and Characteristics, Proceedings of the $29^{\text {th }}$ International Cement Seminar, Rock Product, San Francisco, California, U.S.A., 1993.

[8] McCord, A.T., Process for Reclaiming Cement Kiln Dust and Recovering Chemical Values There From, U.S. Patent No. 4,031,184, 1977.

[9] Young, G.L., and Morrison, G.L., Passamaquoddy Technology Recovery Scrubber at the Dragon Products Company, Inc. Cement Plant, Rock Products, $27^{\text {th }}$ International Cement Seminar, Atlanta, Georgia, U.S.A., 1991.

[10] Fuller Company, Fuller Kiln Dust Recovery System, Bethlehem, Pennsylvania, U.S.A., 1992.

[11] Dean, T.C., Recovering Alkali Metal Salts From Cement Kiln Gases by the Steps of Condensing Leaching and Crystallizing, U.S. Patent No. 3,647,395, 1972.

[12] Singleton, F.H., and Bruce, J.W., Treatment of Cement Kiln Flue Dust, U.S. Patent No. 3,925,534, 1975.

[13] Bhatty, M.S.Y., Use of Cement Kiln Dust in Blended Cements, World Cement Technology, London, U.K., Vol. 15, No. 4, PP. 126-134, 1984.

[14] Bhatty, M.S.Y., Kiln Dust Cement Blends, Evaluated, Rock Products, Chicago, Illinois, U.S.A., Vol. 88, No. 10, PP. 47-65, 1984.

[15] Bhatty, M.S.Y., Use of Cement Kiln Dust in Blended Cements: Alkali- Aggregate Reaction Expansion, World Cement Technology, London, U.K., Vol. 16, No. 10, PP. 386-392, 1984.

[16] Bhatty, M.S.Y., Properties of Blended Cement Made with Portland Cement, Cement Kiln Dust, Fly Ash, and Slag, $8^{\text {th }}$ International Congress on Chemistry of Cement, Rio de Janeiro, Brazil, Theme 3, Vol. IV, PP. 118-127, 1986.

[17] Sanduo, T., Some Views on Cement Specifications, $8^{\text {th }}$ International Congress on Chemistry of Cement, Rio de Janeiro, Brazil, Vol. VI, PP. 296-299, 1986

[18] Daugherty, E.D. and Funnell, J.E., The incorporation of Low Levels of By-Products in Portland Cement and the Effects of Cement Quality, Cement, Concrete, and Aggregates, American Society for Testing and Materials, Philadelphia, Pennsylvania, U.S.A., Vol. 5, No. 1, PP. 14-20, 1983.

[19] El-Didamony, H., Helmy, I. M., and Amer, A.A., Utilization of Cement Dust in Blended Cement, Pak. J. Sci. Ind. Res., Vol. 35, 1992. 
[20] Strunge, J., Knoefe, D., and Dreiler, I., Zem-Kalk-Gips, Vol. 38 (3), P. 150, 1985.

[21] Strunge, J., Knoefe, D., and Dreiler, I., Zem-Kalk-Gips, Vol. 38 (8), P. 441, 1985.

[22] Klemm, W. A., Kiln Dust Utilization, Martin Marietta Laboratories Report MML TR 80-12, Baltimore, Maryland, U.S.A., 1980.

[23] Abo-El-Enein, S. A., Utilization of Cement Kiln Dust in Cement Industry and Building Products, First International Symposium on the Cement Industry, Assiut, Egypt, 8-10 Nov. 1997.

[24] Mosleh, A. M., Evaluation of By-Pass Dust for the Production of Blended Cement Containing B. F. Slag, MSc. Thesis, Institute of Environmental Studies and Research, Ain Shams University, Egypt, 1996.

[25] Shoaib, M. M., Balaha, M. M., and Abdel-Rahman, A. G., Influence of Cement Kiln Dust Substitution on the Mechanical Properties of Concrete, Cement and Concrete Research, Vol. 30, PP. 371-377, 2000.

[26] El-Sayed, H. A., Gaber, N. A., Hanafi, S., and Mhran, M. A., Reutilization of By-Pass Kiln Dust in Cement Manufacture, International Conference on Blended Cement in Construction, Sheffield, UK, 1991.

[27] Batis, G., Rakanta, E., Sideri, E., Chniotakis, E., and Papgeorgiou, A., Advantages of Simultaneous Use of Cement Kiln Dust and Blast Furnace Slag, International Conference on Challenges of Concrete Construction, University of Dundee, UK, 2002.

[28] Al-Harthy, A. S., Taha, R., and Al-Maamary, F., Effect of Cement Kiln Dust (CKD) on Mortar and Concrete Mixtures, Construction and Building Materials, in Press, 2002.

[29] Papadakis, V. G., Effect of Fly Ash on Portland Cement Systems, Part I Low-Calcium Fly Ash, Cement and Concrete Research, vol. 29, PP. 1727-1736, 1999.

[30] Paya, J., Monzo, J., Borrachero, M. V., Peris_Mora, E., and Amahjour, F., Mechanical Treatment of Fly Ashes, Part IV: Strength Development of Ground Fly Ash-Cement Mortars Cured at Different Temperatures, Cement and Concrete Research, Vol. 30, PP. 543-551, 2000.

[31] Wu, Z., and Naik, T. R., Properties of Concrete Produced from Multicomponent Blended Cements, Cement and Concrete Research, Vol. 32, PP. 1937-1942, 2002

[32] Siddique, R., Effects of Fine Aggregate Replacement with Class F Fly Ash on the Mechanical Properties of Concrete, Cement and Concrete Research, in Press, 2002.

[33] Erdogdu, K., and Turker, P., Effects of Fly Ash Particle Size on Strength of Portland Cement Fly Ash Mortars, Cement and Concrete Research, Vol. 28, PP. 1217-1222, 1998.

[34] Bouzoubaa, N., Zhang, M. H., and Malhotra, V. M., Laboratory-Produced High-Volume Fly Ash Blended Cements, Compressive Strength and Resistance to the Chloride-Ion Penetration of Concrete, Cement and Concrete Research, Vol. 30, PP. 1037-1046, 2000.

[35] Gangadhara, M., Kolay, P., and Singh, D., Thermal Characteristics of A Class Fly Ash, Cement and Concrete Research, Vol. 28, PP. 841-846, 1998.

[36] Guerrero, A., Goni, S., Macias, A., and Luxan, M., Mechanical Properties, Pore Size Distribution, and Pore Solution of Fly Ash - Belite Cement Mortars, Cement and Concrete Research, Vol. 29, PP. 1753-1758, 1999.

[37] Papadakis, V. G., Effect of Fly Ash on Portland Cement Systems, Part II High-Calcium Fly Ash, Cement and Concrete Research, Vol. 30, PP. 1647-1654, 2000.

[38] Bouzoubaa, N., Zhang, M. H., and Malhotra, V. M., Mechanical Properties and Durability of Concrete Made with High-Volume Fly Ash Blended Cements Using a Coarse Fly Ash, Cement and Concrete Research, Vol. 30, PP. 1393-1402, 2001.

[39] Jueshi, Q., Caijun, S., and Zhi, W., Activation of Blended Cements Containing Fly Ash, Cement and Concrete Research, Vol. 31, PP. 1121-1127, 2001.

[40] Palomo, A., Grutzek, M. W., and Blanco, M., T., Alkali-Activated Fly Ashaes, A Cement for the Future, Cement and Concrete Research, Vol. 29, PP. 1323-1329, 1999.

[41] Fan, Y., Yin, S., Wen, Z., and Zhong, J., Activation of Fly Ash and Its Effects on Cement Properties, Cement and Concrete Research, Vol. 29, PP. 467-472, 1999.

[42] ASTM C 187-94, Standard Test Method for Normal Consistency of Hydraulic Cement, 
American Society for Testing and Materials, Vol. 04.01, Cement; Lime; Gypsum. Philadelphia, PA, U.S.A., 1994.

[43] ASTM C 191-94, Standard Test Method for Time of Setting of Hydraulic Cement by Vicate Needle, ibid.

[44] ASTM C 109-94, Standard Test Method for Compressive Strength of Hydraulic Cement Mortars (using 2-in. or 50-mm Cube Specimens), ibid.

[45] ASTM C 190-94, Standard Test Method for Tensile Strength of Hydraulic Cement Mortars, ibid. 


\title{
الإسقادة من غبار فرن الإسمنت والرماد المظاير في تحضير الخطلت الإسمنتية في المملكة العربية للسعوية
}

\author{
محمد عبدالرحن داعوس \\ قمم الهنهسة الكيميائية وهنهسة المواد ، جلمعة المالك عبدالعزيز

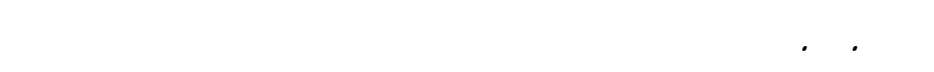 \\ mdaous@kaau.edu.sa
}

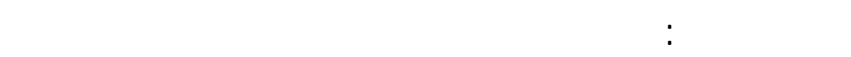

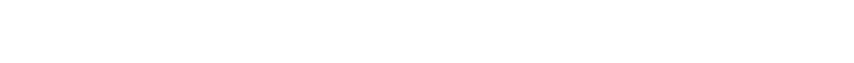

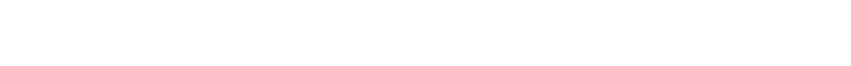

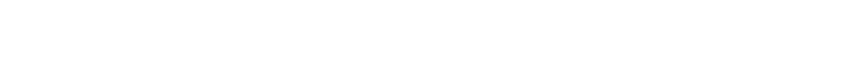

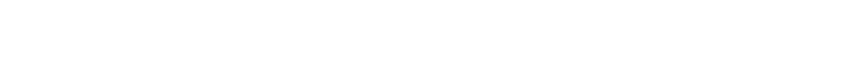

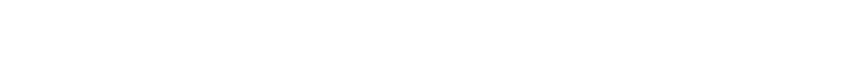

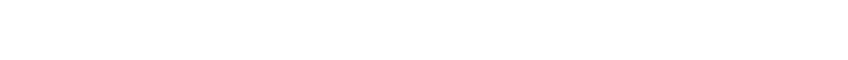

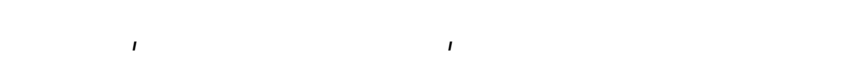

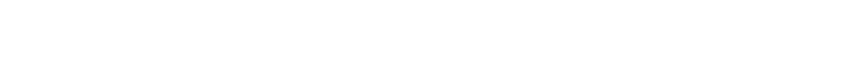

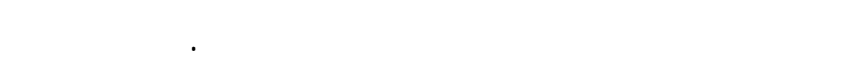

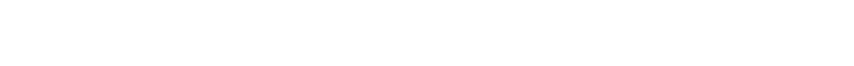

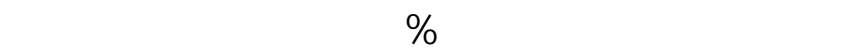

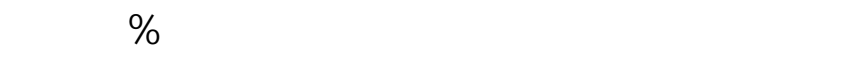

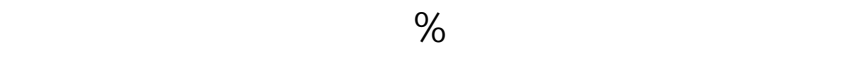

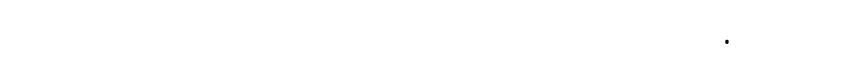

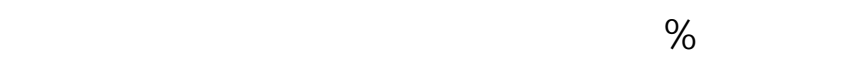

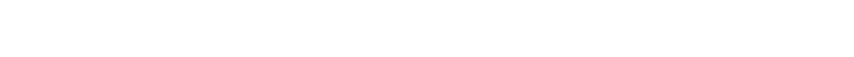

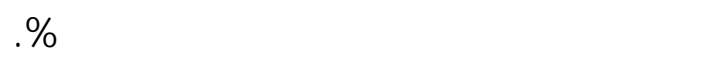

